This article was downloaded by: [National Taiwan University]

On: 17 December 2008

Access details: Access Details: [subscription number 788846425]

Publisher Taylor \& Francis

Informa Ltd Registered in England and Wales Registered Number: 1072954 Registered office: Mortimer House, 37-41 Mortimer Street, London W1T 3JH, UK

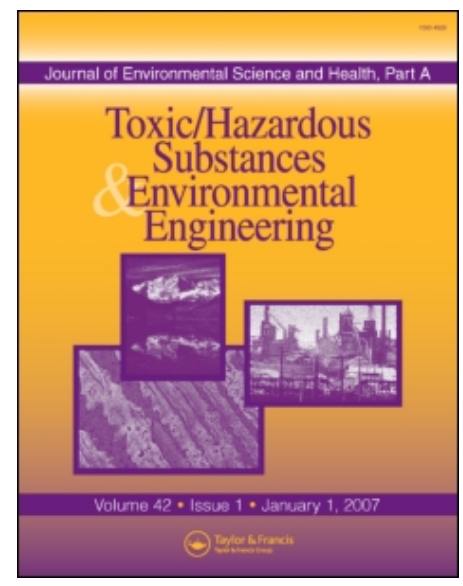

Journal of Environmental Science and Health, Part A

Publication details, including instructions for authors and subscription information:

http://www.informaworld.com/smpp/title content=t713597268

\title{
VARIATION OF TOXICITY DURING THE OZONATION OF MONOCHLOROPHENOLIC SOLUTIONS
}

Neng-Chou Shang a; Yue-Hwa Yu a; Hwong-Wen Ma ${ }^{a}$

a Graduate Institute of Environmental Engineering, National Taiwan University, Taipei, Taiwan, ROC

Online Publication Date: 31 January 2002

To cite this Article Shang, Neng-Chou, Yu, Yue-Hwa and Ma, Hwong-Wen(2002)'VARIATION OF TOXICITY DURING THE OZONATION OF MONOCHLOROPHENOLIC SOLUTIONS',Journal of Environmental Science and Health, Part A,37:2,261 — 271

To link to this Article: DOI: $10.1081 /$ ESE-120002586

URL: http://dx.doi.org/10.1081/ESE-120002586

PLEASE SCROLL DOWN FOR ARTICLE

\footnotetext{
Full terms and conditions of use: http://www.informaworld.com/terms-and-conditions-of-access.pdf

This article may be used for research, teaching and private study purposes. Any substantial or systematic reproduction, re-distribution, re-selling, loan or sub-licensing, systematic supply or distribution in any form to anyone is expressly forbidden.

The publisher does not give any warranty express or implied or make any representation that the contents will be complete or accurate or up to date. The accuracy of any instructions, formulae and drug doses should be independently verified with primary sources. The publisher shall not be liable for any loss, actions, claims, proceedings, demand or costs or damages whatsoever or howsoever caused arising directly or indirectly in connection with or arising out of the use of this material.
} 
J. ENVIRON. SCI. HEALTH, A37(2), 261-271 (2002)

\title{
VARIATION OF TOXICITY DURING THE OZONATION OF MONOCHLOROPHENOLIC SOLUTIONS
}

\author{
Neng-Chou Shang, ${ }^{*}$ Yue-Hwa Yu, and \\ Hwong-Wen Ma \\ Graduate Institute of Environmental Engineering, \\ National Taiwan University, 71 Chou-Shan Road, \\ Taipei, Taiwan, ROC
}

\begin{abstract}
This study investigates the variation of toxicity during ozonation of 2-chlorophenol (2-CP), 3-chlorophenol (3-CP) and 4-chlorophenol (4-CP) in neutral condition. Acute toxicity of pure chlorophenols (CPs) and their ozonated intermediates was evaluated by Microtox assay. The results revealed that the intermediates of oxidized CPs induced new toxicity during the early stage of ozonation, and the ozonated 2-CP showed higher degree of toxicity increase than 3-CP and 4-CP. The maximum toxicity normally occurred before the maximum color intensity was monitored, while ozone dosage applied was within $1 \mathrm{mg}$ of ozone per $\mathrm{mg}$ of initial CPs. This increasing toxicity was mainly contributed from ozonated intermediates. Formation of chlorocatechols, chloromuconic acids and hydroxylated/chlorinated dimeric compounds were detected in ozonation of CPs. These chlorinated by-products may cause greater toxicity than the parent chlorophenols. The required ozone dosage to detoxify the CPs solution into a complete non-toxic condition follows the order: 4-CP > $3-\mathrm{CP}>2-\mathrm{CP}$.
\end{abstract}

*Corresponding author. E-mail: shangnc@hotmail.com 
Key Words: Ozonation; Monochlorophenols; Toxicity; Microtox; $\mathrm{EC}_{50}$

\section{INTRODUCTION}

Many aromatic compounds, including the chloro-, nitro-substituted aromatic compounds or substituted phenols have been reported to be quite bioresistant in the nature and in treatment plants. One of these compounds, the chlorophenols (CPs) are typically biorefractory or toxic in the aqueous environment due to their chloro substituent (1). Related studies have examined the feasibility of using partial oxidation of chlorophenols by ozone or other oxidants (Advanced Oxidation Processes, AOPs) to promote biodegradability for subsequent biological treatment and to reduce the toxicity of effluent (2-5). In general, the byproducts formed in these oxidation processes are mainly low molecular weight (organic acids) or hydroxylated compounds, which are presumed to be more biodegradable or less toxic than their parent compounds (6,7). Therefore, Adams et al. (8) indicated that the ozonation of 4-CP and 2,4-dichlorophenol (DCP) significantly enhanced their biodegradability by the unacclimated microbial seed obtained from a domestic wastewater treatment plant's activated sludge, and that the ultimate COD (Chemical Oxygen Demand) removal increased about $50 \%$ for these two chlorophenols. Trapido et al. (2) also reported that ozonation of CPs (2-CP, 4-CP, 4-chlororesorcinol, 6-chloro- $m$-cresol and 2,4-dichlorophenols) decreases their toxicity according to the Daphnia magna $24 \mathrm{~h}$ toxicity test when ozone treatment lead to $90-95 \%$ removal of CPs.

On the other hand, the toxic intermediates of oxidative treatment prior to the detoxification of the chlorinated aromatic compounds have been reported (9-11). Hirvonen et al. (9) reported that the hydroxylation of chlorophenols and formation of dimeric intermediates were involved in the oxidation of chlorophenols by ozone and $\mathrm{UV} / \mathrm{H}_{2} \mathrm{O}_{2}$ processes. Hydroxylated chlorophenols, chlorodihydroxybiphenyls and dichlorodihydroxybiphenyls were formed in both oxidation treatments of monochlorophenols (2-CP and 4-CP). These byproducts showed the characteristics of high molecular weight or the presence of chlorinated intermediates, which present toxic concern. Svenson and Hynning (10) indicated that photolytic degradation of 2,4,6-trichlorophenol was found to increase aqueous toxicity measured by the Microtox bioassay system, and this increasing toxicity was mainly generated from 3,5-dichlorocatechol formed. In light of above development, oxidation treatment of mono-chlorophenols by ozone is studied in this investigation, and attention is focused on the variation of toxicity. Acute toxicity of pure CPs and their intermediates are evaluated by the Microtox toxicity assay (12). 


\section{MATERIALS AND METHODS}

\section{Process of Ozonation}

Figure 1 shows a schematic diagram of the ozonation apparatus employed as a semi-batch type. Ozonation is performed in a lab-scale bubble column reactor ( $327 \mathrm{~mm}$ high and $70 \mathrm{~mm}$ diameter) with a magnetic stirrer. All the components in this system are made from acrypoly glass, Teflon or stainless steel. The ozone generator used was manufactured by JEU TU CO., Japan (Series No, SG-01A-PSA4). The ozone gas was introduced into a diffuser in the bottom of reactor and the concentration in the feed-gas was maintained at $77.0 \mathrm{mg} / 1\left(\left[\mathrm{O}_{3}\right]_{\text {in }}\right)$. The gas flow rate was $976 \mathrm{ml} / \mathrm{min}(q)$ in all experiments. The concentration of ozone gas was measured by the potassium iodide technique based on the Standard Methods (13). Table 1 lists other detailed operating conditions of ozonation.

The mono-chlorophenols used in this study were 2-chlorophenol, 3-chlorophenol and 4-chlorophenol. They were obtained from Merck (reagent grade). The initial concentrations of the test CPs were set at $100 \mathrm{mg} / 1$ $(0.78 \mathrm{mM})$ and $200 \mathrm{mg} / 1(1.56 \mathrm{mM})$. Since the ozone dosage applied was maintained at $1.57 \mathrm{mmol} / \mathrm{min}\left(q \times\left[\mathrm{O}_{3}\right]_{\text {in }}=0.976 \mathrm{~L} / \mathrm{min} \times 77.0 \mathrm{mg} / 1=\right.$ $75.2 \mathrm{mg} / \mathrm{min}$ ), the ratio values of compound concentration $(\mathrm{mM}) /$ ozone dosage $(\mathrm{mmol} / \mathrm{min})$ was 1 and 0.5 . The volume of reaction solution is $1000 \mathrm{ml}$ and Milli-Q water was used in all experiments. The $\mathrm{pH}$ was fixed at $\mathrm{pH} 7$ in all ozonation. A pH controller (SUNTEX, pH/ORP Controller PC-310), an adding pump (Cole-Parmer 7553-80) and $0.2 \mathrm{~N} \mathrm{NaOH}$ or $\mathrm{H}_{2} \mathrm{SO}_{4}$ solution was utilized to control $\mathrm{pH}$ during ozonation. Next, the color formation during ozonation was measured by a UV/VIS spectrophotometer (Metertek SP-830) and observing the absorbance at $420 \mathrm{~nm}$.

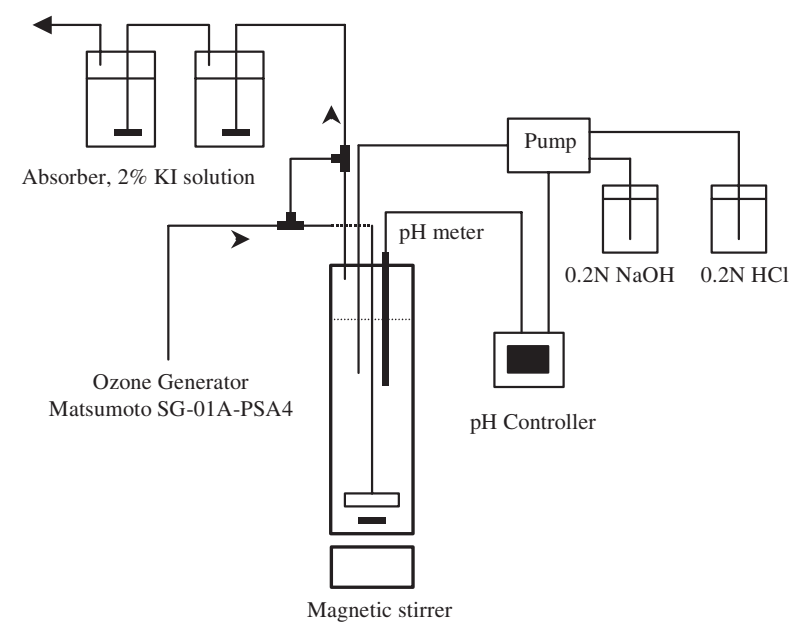

Figure 1. Assemblage of ozonation system. 
Table 1. Operating Conditions of Ozonation

\begin{tabular}{|c|c|}
\hline \multicolumn{2}{|c|}{ Gas Phase } \\
\hline Flow rate, $q$ & $976 \mathrm{ml} / \mathrm{min}$ \\
\hline Pressure & $1 \mathrm{~kg} / \mathrm{cm}^{2}$ \\
\hline Influent ozone & \\
\hline concentration $\left[\mathrm{O}_{3}\right]_{\text {in }}$ & $77.0 \mathrm{mg} / 1$ \\
\hline $\begin{array}{l}\text { Ozone dosage } \\
\text { applied, } q \times\left[\mathrm{O}_{3}\right]_{\text {in }}\end{array}$ & $\begin{array}{l}75.2 \mathrm{mg} / \mathrm{min} \\
(1.57 \mathrm{mmol} / \mathrm{min})\end{array}$ \\
\hline \multicolumn{2}{|c|}{ Liquid Phase } \\
\hline Bubble column reactor & $\begin{array}{l}327 \mathrm{~mm} \text { high, } \\
70 \mathrm{~mm} \text { diameter }\end{array}$ \\
\hline Volume of solution & $1000 \mathrm{ml}$ \\
\hline Initial reaction & $100 \mathrm{mg} / 1(0.78 \mathrm{mM})$ \\
\hline concentration & $200 \mathrm{mg} / 1(1.56 \mathrm{mM})$ \\
\hline $\mathrm{pH}$ condition & 7 \\
\hline
\end{tabular}

\section{Analytical Methods and Equipments}

The CPs concentration and their intermediates during ozonation were analyzed by HPLC (Bio-Rad 1350) equipped with a UV/VIS spectrophotometer (Bio-Rad 1706) employing wavelength at $280 \mathrm{~nm}$ and a C18 reverse-phase column (Phenomenex). The mobile phase consisted of acetonitrile, water and acetic acid, regulated as 580:420:5.7 by volume ratio. A Finnngan TSQ-700 liquid chromatograph (LC) with mass spectrometry (MS) and an electrospray ionization (ESI) system was employed to identify the intermediates. The concentration of chloride ion was measured by using a Dionex 2000i ion chromatograph (IC) with a Dionex AS4A anion separator column. A TOC analyzer (O-I-Analytical, model 700) was employed to measure the total carbon concentration (TOC) of ozonated solution.

\section{Microtox Toxicity Test}

Acute toxicity of the pure compounds and solutions of their ozonated intermediates was measured by the Microtox toxicity technique, using Photobacterium phosphoreum. Analysis was according to the standard Microtox test procedures using a Microtox Analyzer (Model 500, Microbics Corp, Carlsbad, CA). In this paper, the $\mathrm{EC}_{50,15 \text { min }}$ value (that is the effective concentration of the sample that causes $50 \%$ inactivation of the test bacteria in $15 \mathrm{~min}$ ) was used to trace the change in toxicity during ozonation. The Microtox test was operated in duplicate with a resulting average CV (Coefficient of Variation) of $15 \%$. The $\mathrm{pH}$ value of all test samples was maintained at 7 to prevent the $\mathrm{pH}$-effect, before toxicity was measured. The microorganism used in the Microtox produces light with peak intensity 
at $490 \mathrm{~nm}$. Consequently, highly colored aqueous samples may cause nonspecific reductions in light level when analyzed according to the standard Microtox assay procedure. Any light level reduction could not be distinguished from one caused by toxicants. Therefore, a color correction procedure was incorporated in this study. The Microtox test of all samples was required to finish the measurement within $48 \mathrm{~h}$ after sampling, and the samples must storage under $4^{\circ} \mathrm{C}$ environment.

The $\mathrm{EC}_{50}$-values expressed as TOC $\left(\mathrm{EC}_{50 \text {, as } \%} \times \mathrm{TOC}\right)$ are used in this study. In order to further discuss the contribution of toxicity for ozonated intermediates, $\mathrm{EC}_{50}$ values are transformed to toxicity units (TU) according to the approach introduced by Brown (14). Toxicity unit values was defined as following equation: $\mathrm{TU}_{i}=C_{i} / \mathrm{EC}_{50, i}$, where $C_{i}$ is the concentration of component $i$. In addition, based on the concept of concentration additivity, the $\mathrm{TU}$ values could be summed up: $\mathrm{TU}_{\text {total }}=\sum \mathrm{TU}_{i}(14,15)$. Based on this, the toxicity unit values were summed up as $\mathrm{TU}_{\text {total }}=\mathrm{TU}_{\mathrm{CPs}}+\mathrm{TU}_{\text {intermediates }}$ in this study. The $\mathrm{TU}_{\text {total }}$ are calculated according to the $\mathrm{TOC}$ value and

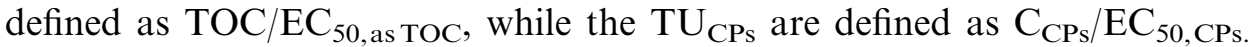
Herein, CPs concentration in ozonated intermediates was measured using HPLC analysis. Based on the above principles, the toxicity unit of ozonated intermediates could be calculated from previously definition of TU additive.

\section{RESULTS AND DISCUSSION}

\section{Variation of Toxicity for Ozonated Chlorophenols}

Figure 2 summarized the results of Microtox $\mathrm{EC}_{50}$ as $\mathrm{TOC}(\mathrm{mg} / \mathrm{L})$ in the ozonation of 2-CP, 3-CP and 4-CP under $\mathrm{pH} 7$ solution. According to the figure, the results revealed that ozonation of CPs significantly induced new aqueous toxicity under various conditions. Namely, the $\mathrm{EC}_{50}$ value of unozonated $\mathrm{CPs}$ was higher than the minimum $\mathrm{EC}_{50}$ value of ozonated intermediates. This increasing toxicity normally reached their peak during ozonation. The variation of $\mathrm{EC}_{50}$ curve kept its downward trend after reaction started until the minimum value $\mathrm{EC}_{50}$ was hit, and further oxidation increased gradually the $\mathrm{EC}_{50}$ value into a non-toxic condition (non-toxic solution was defined as Microtox $\mathrm{EC}_{50}$ was over $100 \%$ in this study). Herein, the reaction concentration of CPs did not affect this phenomenon of increasing toxicity. Regarding the timing of maximum toxicity occurred, it generally happened at early stage of ozonation whether the concentration of CPs was high or low conditions. According to the results in Table 2, maximum toxicity could be observed at the moment when the ozone dosage applied did not exceed the initial amount of CPs. Namely, this increasing toxicity could reach its highest value when the ozone dosage applied was within $1 \mathrm{mg}$ of ozone per $\mathrm{mg}$ of initial CPs. 


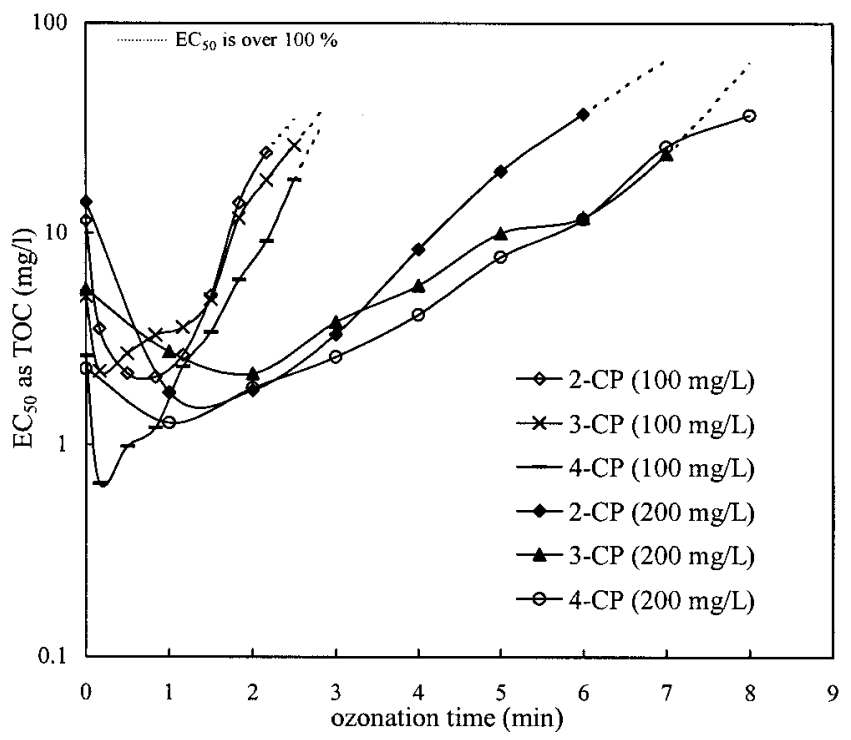

Figure 2. The variation of $\mathrm{EC}_{50}$ as TOC with time during the ozonation of 2-CP, 3-CP and 4-CP (100 and $200 \mathrm{mg} / \mathrm{l})$ in $\mathrm{pH} 7$ condition.

Table 2. Toxicity and Ozone Dosage Applied Results of Ozonation of Chlorophenols

\begin{tabular}{|c|c|c|c|c|c|c|c|}
\hline \multirow[b]{2}{*}{ Concentration $(\mathrm{mg} / \mathrm{l})$} & & \multicolumn{2}{|c|}{$2-\mathrm{CP}$} & \multicolumn{2}{|c|}{$3-\mathrm{CP}$} & \multicolumn{2}{|c|}{ 4-CP } \\
\hline & & 100 & 200 & 100 & 200 & 100 & 200 \\
\hline $\mathrm{EC}_{50}$ as $\mathrm{TOC}(\mathrm{mg} / \mathrm{l})$ & $\begin{array}{l}t_{\mathrm{O}}^{\mathrm{a}} \\
t_{\mathrm{M}} \mathrm{b}\end{array}$ & $\begin{array}{r}11.39 \\
2.08\end{array}$ & $\begin{array}{r}13.98 \\
1.76\end{array}$ & $\begin{array}{l}5.0 \\
2.22\end{array}$ & $\begin{array}{l}5.4 \\
2.17\end{array}$ & $\begin{array}{l}2.62 \\
0.653\end{array}$ & $\begin{array}{l}2.27 \\
1.27\end{array}$ \\
\hline $\mathrm{TU}_{\text {total }}$ & $\begin{array}{l}t_{\mathrm{o}} \\
t_{\mathrm{M}}\end{array}$ & $\begin{array}{r}4.0 \\
20.4\end{array}$ & $\begin{array}{r}7.5 \\
57.4\end{array}$ & $\begin{array}{l}10.6 \\
23.2\end{array}$ & $\begin{array}{l}20.4 \\
47.4\end{array}$ & $\begin{array}{l}20.5 \\
80.2\end{array}$ & $\begin{array}{l}46.9 \\
81.5\end{array}$ \\
\hline $\begin{array}{l}\mathrm{O}_{3} \text { applied } \\
\left(\mathrm{O}_{3}, \mathrm{mg} / \text { initial }\right. \\
\quad \mathrm{CPs}, \mathrm{mg})\end{array}$ & $\begin{array}{l}t_{\mathrm{M}} \\
\text { Detoxify } \\
\text { into non-toxic }\end{array}$ & $\begin{array}{r}0.62 \\
>1.63\end{array}$ & $\begin{array}{r}0.38 \\
>2.25\end{array}$ & $\begin{array}{r}0.13 \\
>1.88\end{array}$ & $\begin{array}{r}0.75 \\
>2.63\end{array}$ & $\begin{array}{r}0.13 \\
>1.88\end{array}$ & $\begin{array}{r}0.38 \\
>3.01\end{array}$ \\
\hline
\end{tabular}

${ }^{\mathrm{a}} t_{\mathrm{O}}$ : unozonated period.

${ }^{\mathrm{b}} t_{\mathrm{M}}$ : ozonated period with maximum toxicity.

In addition, 2-CP showed higher degree of toxicity increase than 3-CP or 4-CP during ozonation in low or high CPs concentration. The maximum TU value of ozonated 2-CP intermediates was 7.7 times to unozonated 2-CP solution (TU, $\left.t_{\mathrm{o}}=7.5 \rightarrow \mathrm{TU}, t_{\mathrm{M}}=57.4\right)$ in $200 \mathrm{mg} / 1$ concentration, while the ozonated 3-CP and 4-CP was 2.3 and 1.7 times to unozonated solutions, respectively (Table 2). This increasing TU value level of ozonated 2-CP and $3-\mathrm{CP}$ under $100 \mathrm{mg} / \mathrm{l}$ concentration were very similar to those of the respective ozonated $200 \mathrm{mg} / \mathrm{l}$ concentration. However, the maximum TU 
value of ozonated 4-CP was 3.9 times as high as unozonated solution in low reaction concentration; this increasing level was higher than in ozonated high concentration.

After maximum toxicity occurred, ozonation of 4-CP reduce the aqueous toxicity back to the original toxicity level faster than others, but it required largest ozone dosage to become the complete non-toxic solution among these ozonated CPs. However, ozonated 2-CP required more ozone dosage to detoxify the toxic intermediates back to original toxicity level, and needed less ozone treatment to become a non-toxic solution than 3-CP and 4-CP (Figure 2). Regarding ozone dosage requirement for detoxifying into non-toxic solution under $200 \mathrm{mg} / 1$ concentration, oxidized 4-CP, 3-CP and 2-CP used about 3.0, 2.6 and $2.3 \mathrm{mg}$ of ozone per $\mathrm{mg}$ of initial $\mathrm{CPs}$, respectively (Table 2). In addition, ozone needed of oxidizing 4-CP, $3-\mathrm{CP}$ and $2-\mathrm{CP}$ in $100 \mathrm{mg} / \mathrm{l}$ concentration for detoxifying the toxicant into a complete non-toxic solution was about $1.9,1.9$ and $1.6 \mathrm{mg}$ of ozone per mg of initial CPs, respectively, and this value was lower than ozonation in high CPs concentration. This result indicated that low CPs concentration or high ozone dosage applied might reduce the existence time of increasing toxicity. Summarizing previously study, ozone requirement of detoxification equaled to the original toxicity situation was following the order 2-CP $>3-\mathrm{CP}>4-\mathrm{CP}$, but if ozone treatment was considered for the non-toxic condition, the order of ozone required was 4-CP> 3-CP $>2-\mathrm{CP}$. The results of this order were closely corresponded to low and high concentration of CPs.

\section{Toxic Contribution of Ozonated Intermediates}

The toxicity unit (TU) of ozonated intermediates was calculated from the additivity of TU value as described earlier. In order to obtain the $\mathrm{TU}_{\mathrm{CPs}}$ value, the purely $\mathrm{CPs} \mathrm{EC}_{50}$ value used in this study was calculated from the average value of unozonated CPs solution under low and high concentration. The Microtox $\mathrm{EC}_{50,15 \mathrm{~min}}(\mathrm{mg} / \mathrm{l})$ of three chlorophenols was 2-CP: 24.7, 3-CP: 9.62 and 4-CP: 4.6, respectively. These Microtox $\mathrm{EC}_{50}$ values of chlorophenols were close to those shown in the published studies $(1,16)$.

The contributions of toxicity units of unozonated CPs or ozonated intermediates and the variation of water parameter were summarized in Figures 3-5. The purely CPs compounds were the only toxicity source before ozonation started. The toxicity of CPs accounted for only a little portion of the total toxicity when the original CPs was reacted into their intermediates, and the increase in TU value was contributed mainly from intermediate compounds. Namely, the by-products were the source of increasing toxicity during oxidized CPs by ozone. Regarding the relationship between toxicity and color formation, the maximum TU value normally occurred a 


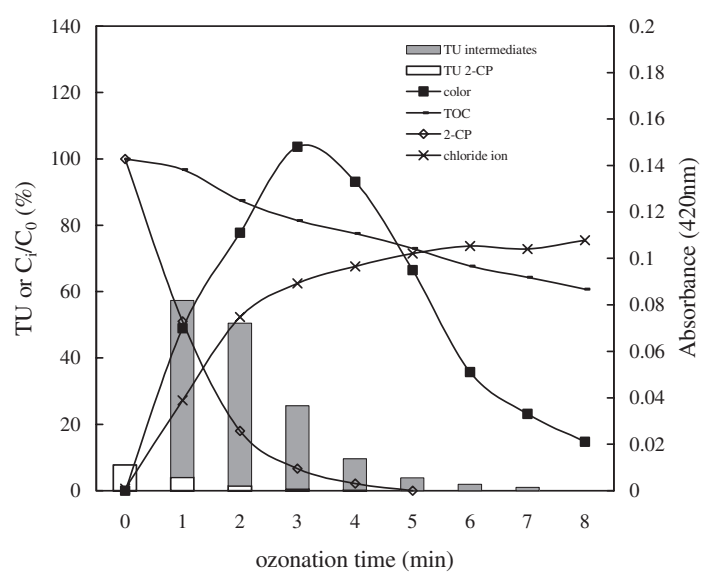

Figure 3. The variation of water parameter and toxicity unit of ozonated 2-CP (200 mg/l) with time in $\mathrm{pH} 7$ condition.

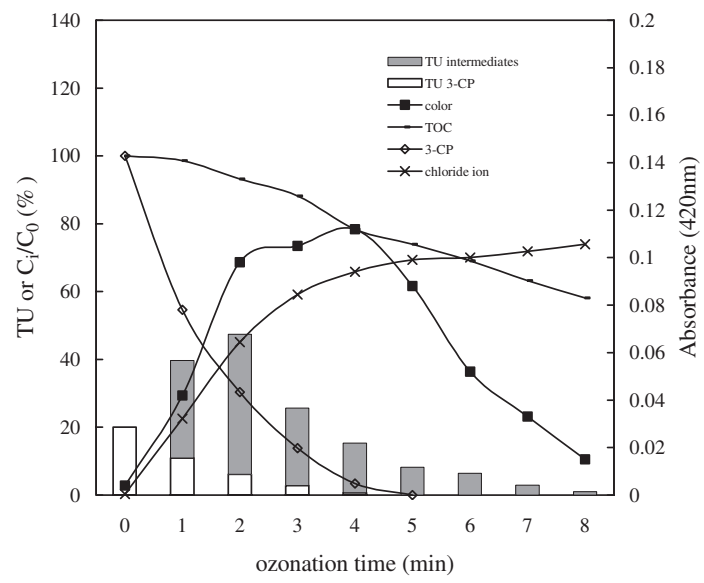

Figure 4. The variation of water parameter and toxicity unit of ozonated 3-CP (200 mg/l) with time in $\mathrm{pH} 7$ condition.

little earlier than when the maximum color intensity expressed at $420 \mathrm{~nm}$ was monitored (Figures 3-5). Therefore, the colored matters might be one of the major intermediates of implying the new aqueous toxicity (17).

The aromatic compounds of containing chloro substituent might be the oxidation intermediates which increasing toxicity. According to the analysis of HPLC and mass spectrometry (MS), ozonated 2-CP, 3-CP and 4-CP formed chlorocatechols and chloromuconic acids as the major intermediates of chlorinated compound (18). Moreover, the intermediates of containing high molecular weights and only little concentration could also be monitored in this study. A compound of molecular weight 252 was detected in ozonated 


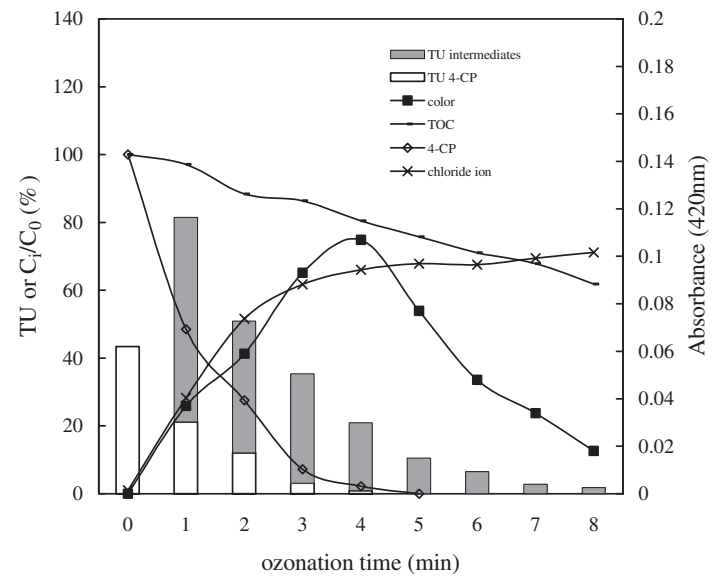

Figure 5. The variation of water parameter and toxicity unit of ozonated 4-CP (200 mg/l) with time in $\mathrm{pH} 7$ condition.

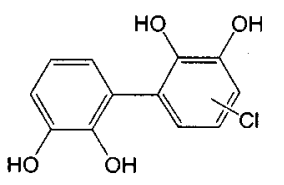<smiles>Oc1ccc(Oc2ccccc2O)cc1Cl</smiles>

(a) MW 252
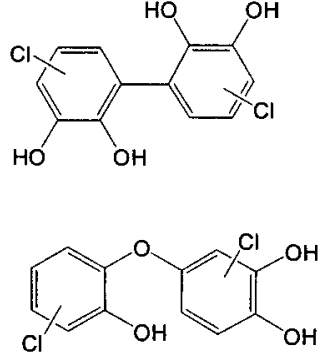

(b) MW 287

Figure 6. The dimeric structure compounds, ozonated intermediates of (a) 2-CP, (b) 3-CP or $4-\mathrm{CP}$.

2-CP, and a compound of molecular weight 287 was found in ozonated 3-CP or 4-CP. These high molecular weights compounds should contain hydroxylated/chlorinated dimeric structures $(9,19)$, and the results are suggested in Figure 6. Hirvonen et al. (9) indicated that the hydroxylated or chlorinated dimeric intermediates were formed during ozonation of 2-CP and 4-CP in acidic solution, and chlorodihydroxylbiphenols $(\mathrm{MW}=220)$ and dichlorodihydroxylbiphenols $(\mathrm{MW}=254)$ were detected. Analysis of these dimeric compounds showed that the dimeric benzene ring was combined through the $\mathrm{C}-\mathrm{C}$ bonding. In addition, Chrostowski et al. (19) also reported that oxidative coupling was the possible mechanism of forming dimeric structure; this reaction formed the $\mathrm{C}-\mathrm{O}-\mathrm{C}$ bonding to combine both benzene ring and form dimeric structure. Summarizing these findings, the results could not indicate very clearly which intermediates implied such increasing toxicity. 
Nevertheless, the aromatic compounds with chlorinated or hydroxylated substitutes might be the oxidation intermediates that incurred an increasing toxicity during ozonation of chlorophenols.

\section{CONCLUSIONS}

This study investigated the variation of toxicity during ozonation of 2-CP, 3-CP and 4-CP in neutral condition. Results of Microtox assay showed that the ozonation of $\mathrm{CPs}$ induced new aqueous toxicity. Ozonation of 2-CP revealed higher level of toxicity increase than 3-CP and 4-CP. The maximum toxicity unit value of ozonated 2-CP intermediates was 7.7 times as high as that of unozonated 2-CP solution. In addition, this increasing toxicity normally reached its peak and a little earlier than when the maximum color intensity was monitored, while the ozone dosage applied was within $1 \mathrm{mg}$ of ozone per $\mathrm{mg}$ of initial CPs. Namely, ozonation of chlorophenols could present the risk of toxic substances more than parent compounds during early stage of ozone treatment. The increasing toxicity was contributed mainly from ozonated intermediates. In this study, chlorocatechols, chloromuconic acids and formation of hydroxylated/chlorinated dimeric compounds were involved in ozonation of CPs. Therefore, further research is required to determine which compounds are major sources of increasing toxicity. Nevertheless, this investigation indicated that ozonation of CPs might generate new toxicity problems if these toxic intermediates are not further oxidized. In addition, ozone requirement of detoxifying into a non-toxic solution was following the order 4-CP $>3-\mathrm{CP}>2-\mathrm{CP}$.

\section{ACKNOWLEDGMENTS}

The authors would like to thank the National Science Council of the Republic of China, Taiwan for financially supporting this research under Contract No. NSC 89-2211-E-002-107.

\section{REFERENCES}

1. Stefan, S.; Joachim, A.; Rainer, B. Quantitative Structure-Toxicity Relationships for 80 Chlorinated Compounds Using Quantum Chemical Descriptors. Chemosphere 1995, 30(12), 2397-2414.

2. Trapido, M.; Veressinina, J.; Hentunen, K.; Hirvonen, A. Ozonation of Chlorophenols: Kinetics, Byproducts and Toxicity. Environ. Tech. 1997, 18, 325-332.

3. $\mathrm{Hu}, \mathrm{S} . \mathrm{T}$; $\mathrm{Yu}, \mathrm{Y} . \mathrm{H}$. Preozonation of Chlorophenolic Wastewater for Subsequent Biological Treatment. Ozone Science \& Engineering 1994, 16, 13-28. 
4. Stockinger, H.; Heinzle, E.; Kut, A.M. Removal of Chloro and Nitro Aromatic Wastewater Pollutants by Ozonation and Biotreatment. Environ. Sci. Tech. 1995, 29(8), 2016-2022.

5. Yu, Y.H.; Hu, S.T. Preoxidation of Chlorophenolic Wastewater for Their Subsequent Biological Treatment. Wat. Sci. Tech. 1994, 29(9), 313-320.

6. Miller, R.M.; Singer, G.M.; Rosen, J.D.; Bartha, R. Sequential Degradation of Chlorophenols by Photolytic and Microbial Treatment. Environ. Sci. Tech. 1988, 22, 1215-1219.

7. Lipczynska-Kochany, E.; Bolton, J.R. Flash Photolysis/HPLC Applications. 2. Direct Photolysis vs. Hydrogen Peroxide Mediated Photodegradation of 4-chlorophenol as Studies by a Flash Photolysis/HPLC Technique. Environ. Sci. Tech. 1992, 26, 259-261.

8. Adams, C.D.; Cozzens, R.A.; Kim, B.J. Effects of Ozonation on the Biodegradability of Substituted Phenols. Wat. Res. 1997, 31(10), 2655-2663.

9. Hirvonen, A.; Trapido, M.; Hentunen, J.; Tarhanen, J. Formation of Hydroxylated and Dimeric Intermediates During Oxidaton of Chlorinated Phenols in Aqueous Solution. Chemosphere 2000, 41, 1211-1218.

10. Svenson, A.; Hynning, P.A. Increased Aquatic Toxicity Following Photolytic Conversion of an Organochloring Pollutant. Chemosphere 1997, 34(8), 1685-1692.

11. Manilal, V.B.; Haridas, A.; Alexander, R.; Surender, G.D. Photocatalytic Treatment of Toxic Organics in Wastewater: Toxicity of Photodegradation Products. Wat. Res. 1992, 26(8), 1035-1038.

12. Nirmalakhandan, N.; Arulgnanendran, V.; Mohsin, M.; Sun, B.; Cadena, F. Toxicity of Mixtures of Organic Chemicals to Microorganisms. Wat. Res. 1994, 28(3), 543-551.

13. APHA. 2350 E. Ozone Demand/Requirement-Semi Batch Method. In Standard Methods for Examination of Water and Wastewater, 18th Ed.; Washington D.C., 1992; pp. 2-42.

14. Brown, V.M. The Calculation of the Acute Toxicity of Mixtures of Poisons to Rainbow Trout. Wat. Res. 1968, 2, 723-733.

15. Brack, W.; Paschke, A.; Segner, H.; Wennrich, R.; Schuurmann, G. Urease Inhibition: A Tool for Toxicity Identification in Sediment Elutriates. Chemosphere 2000, 40, 829-834.

16. Blum, D.J.W.; Speece, R.E. A Database of Chemical Toxicity to Environmental Bacteria and its Use in Interspecies Comparisons and Correlations. J. WPCF. 1991, 63(3), 198-207.

17. Shang, N.C.; Yu, Y.H. The Biotoxicity and Color Formation from Ozonation of Wastewater Containing Phenol and Aniline. J. Environ. Sci. Heal. A. 2001, A36(3), 383-393.

18. Kuo, C.H.; Huang, C.H. Aqueous Phase Ozonation of Chlorophenols. J. Hara. Materials 1995, 41, 31-45.

19. Chrostowski, P.C.; Dietrich, A.M.; Suffet, I.H. Ozone and Oxygen Induced Oxidative Coupling of Aqueous Phenolics. Wat. Res. 1983, 17(11), 1627-1633.

Received July 20, 2001 


\section{Request Permission or Order Reprints Instantly!}

Interested in copying and sharing this article? In most cases, U.S. Copyright Law requires that you get permission from the article's rightsholder before using copyrighted content.

All information and materials found in this article, including but not limited to text, trademarks, patents, logos, graphics and images (the "Materials"), are the copyrighted works and other forms of intellectual property of Marcel Dekker, Inc., or its licensors. All rights not expressly granted are reserved.

Get permission to lawfully reproduce and distribute the Materials or order reprints quickly and painlessly. Simply click on the "Request

Permission/Reprints Here" link below and follow the instructions. Visit the U.S. Copyright Office for information on Fair Use limitations of U.S. copyright law. Please refer to The Association of American Publishers' (AAP) website for guidelines on Fair Use in the Classroom.

The Materials are for your personal use only and cannot be reformatted, reposted, resold or distributed by electronic means or otherwise without permission from Marcel Dekker, Inc. Marcel Dekker, Inc. grants you the limited right to display the Materials only on your personal computer or personal wireless device, and to copy and download single copies of such Materials provided that any copyright, trademark or other notice appearing on such Materials is also retained by, displayed, copied or downloaded as part of the Materials and is not removed or obscured, and provided you do not edit, modify, alter or enhance the Materials. Please refer to our Website User Agreement for more details.

\section{Order now!}

Reprints of this article can also be ordered at http://www.dekker.com/servlet/product/DOI/101081ESE120002586 